\title{
Household Inward Remittances And Banking Sector Development: The Nigerian Experience (1977 - 2014)
}

\author{
Ogboi Charles Ph.D \\ Department of Economics, Accounting \& Finance \\ Bells University of Technology \\ Ogun State- Nigeria \\ Prof. John Emeka Ezike \\ Department of Finance \\ University of Lagos \\ Lagos State
}

\begin{abstract}
There has been a massive inflow of diaspora remittances into the Nigerian economy in recent times. However, there are concerns over whether or not inward remittances have any significant effect on the banking sector development in Nigeria. This study sought to: (i) examine the trend of household inward remittances and banking sector development in Nigeria; (ii) analyse the effect of inward remittances on banking sector development in Nigeria. Annual time series data were sourced from World Development Indicators (WDI) (2015) edition of the world bank for the period 1977 2014. We employed both descriptive statistics in the form of graph and Generalised Method Moment instrumental variables (GMM-IV) estimator to examine the inward remittances - banking sector development nexus Nigeria. Results show that inward remittances have positive but statistically insignificant effect on banking sector development in Nigeria $(\beta=0.0727 ; t=0.5165)$. It is therefore recommended amongst others, that Nigerian banks develop remittance-linked financial products for Nigerians in Diaspora and remittance recipient households instead of treating remittance as a one-off transaction without value addition.
\end{abstract}

Keywords: inward remittances, banking sector development, value addition, GMM

\section{INTRODUCTION}

Household inward remittances as private monetary transfers by migrants to their home countries have increased substantially since 2005. Inward remittances to developing countries reached \$430bn in 2011 from \$333bn in 2010(World Bank 2012). World Bank(2013) forecasts that it would increase to about $\$ 500$ bn by 2015 . Remittance inflow into Nigeria has surpassed other foreign exchange flows like Foreign Direct Investment (FDI) and Official Development Assistance (ODA) both in absolute terms and as percentage of GDP (World Bank, 2012).

Remittances have been receiving research attention from both people in academics and policy makers. This increased research attention could be attributed to empirical evidences suggesting that inward remittances remain an important source of investment finance for individuals and families to cope with poverty and economic crisis.

Abdih, Chami, Dagher, and Montiel (2012), observed that inward remittances help improve household welfare by lifting families out of poverty and insuring them against income shocks. Adams and Page (2005); Chami, Barajas, Cosimo, Fullenkamp, Gapen, and Montiel (2008);), Catteneo (2008) posit that households that receive remittances spend less on consumption and 
more on investment, while Kalim and Shahbaz (2009) see remittances as useful means for poverty reduction.

Although, microeconomic evidence proves remittance to be a resilient source of investment finance, its macroeconomic impact especially on output growth is still inconclusive. There are several studies from developed countries that document the impact of remittance on economic growth, but how and through which channel(s) remittances affect growth is still an open question among financial economists. In search of the channel(s) through which remittances affect growth Aggarwal Asli, and Mari (2006); Giuliano and Ruiz-Arranz (2009); and Gupta, Pattillo, and Wagh (2009), examined the relationship amongst remittances, financial development and economic growth, and produced mixed results. There are three schools of thought on the macroeconomic impact of remittance; the pessimistic school, optimistic school and, recently, middle of the road approach. While the optimistic school sees remittance as growth enhancing, the pessimistic school sees it as growth retarding, thereby leaving the academia in a quandary.

It has since been discovered that financial development promotes economic growth (McKinnon 1973; King \& Levine, 1993). According to Giuliano and Ruiz-Arranz, (2009), the relationship among remittances, financial development and economic growth is "a priori" ambiguous. On the one hand, remittance could complement a country's financial system by channeling remittance inflow to projects that yield high returns and thereby enhance economic growth. On the other hand, remittance can substitute for a shallow financial system by providing finance to young entrepreneurs to start productive investments.

Access to credit is among the biggest problems confronting entrepreneurs in developing economies (Paulson \& Towsend 2000). Besides, several empirical studies suggest that credit constraint occasioned by inefficient financial market is a major hindrance to economic growth especially economies that are characterized by high level of income inequality (Galor \& Zeira, 1993; Banerjee \& Newman, 1993; Aghion \& Bolton, 1997).

In a shallow financial market, entrepreneurs that do not possess enough funds forego potentially profitable investment opportunities. The role of investment in the remittanceeconomic growth nexus is still being debated in the academia. Prior studies by Guliano and Ruiz-Arranz, (2005) suggest three possibilities.

First, remittances could help alleviate credit constraints on the poor, substituting for lack of financial development, thereby improving the allocation of capital and consequently accelerating economic growth. This implies that the role of banking system cannot be underestimated in the remittance-growth nexus. Second, that remittances have the tendency of discouraging labour supply in more financially developed economies because in a developed capital market, remittances are not essential to finance investment, since the needs for credit and insurance can easily be met by a well functioning banking system.

Third, there are documented evidences that inward remittances tend to be more pro cyclical where the financial system is less developed. This implies that pro cyclical remittances are more likely to be motivated by investment opportunities rather than by altruistic reasons. In analyzing the impact of remittances on economic growth, Guliano and Ruiz-Arranz, (2009) focused on the importance of investment and emphasized the contributory effect of the banking system.

The conventional wisdom has always been that since some countries' financial systems are 
more developed than others, inward remittances will have differential effect across countries. The investment channel which is based on New Economics of Labour Migration approach confirmed the above reasoning and maintained that some economies rely on inward remittances than others for investment purposes. As such, policy that encourages larger inflow of remittances that could be channeled towards investment should be formulated. In this dimension, remittances will have a greater impact on economies that have a well developed banking system. The economic impact of inward remittances, according to Mundaca, (2005) implies that in an economy where the financial system is characterized by small banks and less healthy banks, the banking system is likely to experience little or no impact of remittances when compared to countries with big healthy and well developed banking systems.

With regards to the Nigerian economy, available data from CBN (2014) shows that inward remittances averaged $\$ 20 \mathrm{bn}$ per annum from 2005 to 2013, yet the banking system is still characterized by many small and uncompetitive banks as indicated by low ratio of credit to private sector to GDP at $36.89 \%$, money supply to GDP averaging $38.7 \%$ in the corresponding period. Besides, the gross domestic product growth rate has been hovering between 6-7\%. These statistics are still the same when compared to the period before the upsurge of remittance inflow.

In an attempt to direct these huge resource inflows into productive use, the Nigerian monetary authorities have embarked on several banking reforms to deepen the banking system. Such measures include, providing saving instruments for remittance recipient households to save out of the remittance receipts, reducing transaction cost on remittance, strengthening the financial system by building confidence in the payment system, fostering enhanced competition in the financial sector and providing a strong regulatory environment framework.

Despite these reform efforts, available information suggests that the bulk of remittances inflow are spent on consumption, debt repayment, housing and consumer durables with little or nothing being invested (World Bank 2013).

The main thrust of this study, therefore, is to empirically assess whether inward remittances impact on banking sector development in Nigeria

\section{OBJECTIVES}

i. Examine the trend of inward remittances and banking sector development in Nigeria

ii. Establish the inward remittances - banking sector development nexus in Nigeria..

\section{HYPOTHESIS}

Ho: There is no significant relationship between inward remittances and banking sector development in Nigeria.

\section{New Economics of Labour Migration (NELM)}

NELM approach as pioneered by Stark and Bloom (1985) and Stark (1991) modelled migration as risk-sharing behaviour of households. Decision to emigrate is anchored on the need to overcome economically difficult situations arising from financial market failures. It is acknowledged in extant literature that credits are grossly unavailable and where available, are very expensive. Therefore in the absence of efficient and accessible insurance and credit system arising from financial market failures, households emigrate in order to diversify household income shocks. 
For NELM the uncertainty of household income is the main reason for migration.

In order to diversify the risk of insufficient household income, households send their members abroad in search of "greener pastures" who in turn send remittances to their relatives left behind. The theory of NELM states that remittances produce positive effect on macroeconomic development of labour sending countries.

Taylor (1999) observed that there is no consensus yet on the developmental perspective of inward remittances. He stated that if there is labour outflow and remittance inflow volatility, then the labour sending country would also experience output growth volatility and Dutch disease syndrome. In their review, Adelman and Taylor (1990) made some critical observations that:

i. For every dollar remittance inflow to Mexico by migrants, GNP increase by $\$ 2.6$ and $\$ 3.17$.

ii. Remittance produce robust GNP(growth) effect when channelled into rural households, whose consumption and expenditure patterns favour tradable goods, but when migrant remittances flow to urban households, larger proportion of the fund leaks out of the recipient country in the form of import demand.

iii. Many of the benefits of remittances inflow impact on recipient and non remittance recipient households.

The New Economics of Labour Migration Theory was built in line with certain historical context of Mexican migration in the United States, and this is precisely the basis for which it was criticized.

\section{EMPIRICAL LITERATURE REVIEW}

There have been debate and controversies on the relationship that exists between international migrant remittances and banking sector development on one hand, and economic growth on the other in both developed and developing countries. Jongqanich (2007); Guliano and Ruiz-Arranz (2008); Bettin and Zazzaro (2008); Cooray (2010) amongst others studied the impact of remittances and financial development on economic growth in developed countries. Studies that were focused on Africa, Sub-Saharan Africa and recently on Nigerian includes; Oke et al., (2011)); Deodat (2011); Nyamongo et al., (2012); and Kanu and Ozurumba (2013); Akinpelu et al., (2013). Overall, the empirical evidence is inconclusive, mixed and controversial. This has been attributed to the ambiguous nature of the effects of remittances on financial development (through the conflicting interaction as to whether remittances play substitution or complementary role in banking sector development.

Guiliano and Ruiz-Arranz (2005) made an attempt to empirically explore the dynamic relationship among inward remittances, financial development and economic growth for seventy three developing countries using panel regression analysis. The authors split the sample period covering 1975 to 2002 into six non-overlapping five year periods. The authors posited that a negative sign of the interacted variable would imply remittances are more efficient in an economy with shallow financial system, indicating a substitutability effect, on the contrary, a positive sign implies a complementary effect, suggesting remittance inflow promote economic growth more in an economy with developed financial system. The authors adopted System Generalized Method of Moment (SGMM) estimate to control for possible endogeneity among the regressor variables. The study found that remittance stimulate output growth in less financially developed economies. However, the authors did not consider countries specific characteristics that could influence the outcome of their findings. 
Aggarwal, et al., (2006) used Balance of Payment(BOP) data on remittance flows received by 109 countries over the period 1975-2007 to study the linkage between workers' remittances and financial sector development. The authors specifically examined whether remittances contribute to the development of the financial sector by increasing the aggregate level of deposits and or the amount of credit extended to private sector by domestic banks. According to the authors, the choice of the two measures of financial development is anchored on the premise that banks play a prominent role in the external finance supply chain and since remittances are perceived as small flows to poor households, it is very unlikely that it could be channeled into the capital market. However, the authors raised the issue of potential endogeneity as a result of data measurement error, reverse causation, and omitted variables bias. In order to address these concerns raised above, the authors used different empirical approaches to examine the relationship between remittance inflows and financial development.

Empirical evidence from this study indicate a positive and significant relationship between remittance and bank deposits and credit to private sector. The authors emphasized that the result of this study is robust to using different estimation techniques and accounting for endogeneity biases arising from omitted factors, reverse causation, and measurement error.

Akkoyulu (2013) investigates whether direct link exist between remittances and financial development in Turkey. According to the author, this present study departs from previous studies that examined the linkage between remittance and financial development that are cross country study that is always with data measurement problems. In an attempt to obtain a clearer picture of the linkage between remittance and financial development in Turkish economy, the author performed a Granger Causality test using Toda and Yamamoto (1995) (TY) procedure. Empirical result shows that the null hypothesis that bank deposits do not granger cause remittances is not rejected, indicating absence of direct link between remittances and financial development of Turkey.

Mahedi (2014) noted that despite the huge inflow of remittance into Bangladesh economy, its impact on economic growth and financial development remained inconclusive. In an attempt to resolve the debate, he conducted a twofold analysis; one to analyze the impact of remittance on economic growth, two, to investigate the interaction of inward remittances with the financial development of Bangladesh in a liberalized regime spanning form 1981 to 2013. In line with the two objectives, the author specified two baseline models as follows:

$$
\mathrm{GDPPC}_{\mathrm{t}}=\alpha \dot{\alpha}+\beta_{1} \text { Remit }_{\mathrm{t}}+\beta_{2} \mathrm{X}_{\mathrm{t}}+\text { et }
$$

Where, $\mathrm{t}$ is the time period from 1981 to 2013. Remit refers to the ratio of remittance to GDP. X is a vector of control variables that includes inflation, openness, population growth.

To explore the relationship between remittance and financial development, the author adopted Aggarwal et al; (2011) as

$$
\mathrm{FD}=\alpha \dot{\alpha}+\beta \mathrm{Remit}_{\mathrm{t}}+\beta_{2} \mathrm{X}_{\mathrm{t}}+\mathrm{et}
$$

Where, $\mathrm{t}$ refers to the time period from 1981 to 2013 Remit refers to the ratio of remittance to GDP. $\mathrm{X}$ is a Vector of control variables. 
Empirical evidence form this study based on Vector Error Correction Model (VECM) and Granger Causality test reveal the following:

i. A long run positive relationship was found between remittance and gross domestic product

ii. Remittance have a significant positive effect on financial development

iii. Economic growth granger causes remittances

iv. Bidirectional relationship was found between remittance and bank deposit and remittance - money supply running form remittance to bank deposit and money supply

Adenutsi (2011) pointed out that a well-functioning financial sector is expected to attract idle funds for financing economic growth and developmental projects in remittance recipient economies. This notwithstanding, a seemingly general consensus among developmental economists exist that the development of the financial sector is a necessary condition for attracting increased external private capital of all sorts. He further noted that inward remittances are an important component of capital flows like export earnings and are therefore a positive determinant of economic growth to the recipient economy. In an attempt to provide further insight into the finance-growth nexus, he verified the age long hypothesis that financial development promotes economic growth through its capacity to attract increased inward remittances to Ghana. The author estimated a dynamic equilibrium correction mechanism model for the period 1987(3)-2007(4) following the Johansen cointegration procedure. This approach produced maximum likelihood estimators of the cointegrating vector. Realizing that all the series were stationary at level and cointegrated, an equilibrium error mechanism and granger causality were estimated. The result obtained from the ECM suggest that even though financial development was found to be detrimental to endogenous growth, it is crucial for mobilizing remittances from International migrants. The granger causality test also revealed a bi-directional causality between financial deepening and migrant remittances inflows, unidirectional causality between remittances and economic growth running from remittances to economic growth was also observed.

Gazar and Kratou (2012) extended previous evidence by investigating the conditional remittances growth relationship in African countries looking specifically as to whether financegrowth nexus is affected by financial development and institutional quality in African countries. Using a sample of 24 African countries over the 1988 to 2011 periods, the authors initially estimated a benchmark model to examine the impact of remittances on economic growth thus

$$
\mathrm{GROWTH}_{\mathrm{it}}=\dot{\alpha}_{\mathrm{i}}+\beta_{\mathrm{o}} \mathrm{REM}_{\mathrm{it}}+\psi \mathrm{Z}_{\mathrm{it}}+\varepsilon_{\mathrm{it}}
$$

In addition to the above equation, the authors specified the second model that incorporates financial development indicator as:

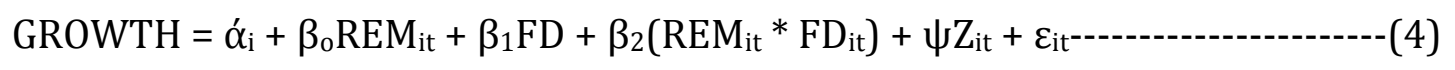

Empirical result of GMM system estimation technique showed that; (i) remittances have a negative effect on economic growth, (ii) financial development and remittances complement to economic growth; (iii) remittances only promote economic growth in countries with robust financial system.

Ajilore and Ikhide (2012) investigated the short-run and long-run impact of remittances on financial development, using country level data on five selected Sub-Saharan African countries. The authors adopted the Autoregressive Distributed Lag (ARDL) framework espoused in 
Pesaran and Shin $(1995,1999)$. The findings of the study revealed the existence of long -run level relationships between remittances and financial development, and evidences in favour of the financial development promoting the developmental role of remittances manifest for Cape Verde, Lesotho, Senegal and Togo, but not for Nigeria.

Ezeoha (2013) examined the interactive impact of financial development on remittances to SSA, Using panel data covering 32 countries from 1995 to 2009. The author formulated a baseline equation as follows:

$$
\log \text { Rem/GDPit }=\alpha^{\prime}+\beta F D_{i t}+\psi \mathrm{X}_{\mathrm{it}}+\mathrm{n}_{\mathrm{i}}+\lambda_{\mathrm{t}}+\varepsilon_{\mathrm{it}}
$$

Where Log REM/GDP is defined as the natural logarithm of the ratio of remittances to gross domestic product; $\mathrm{FD}_{\mathrm{it}}$ represents each of the alternative proxies of financial development, $\mathrm{X}_{\mathrm{it}}$ is a vector of the financial and institutional variables. $n_{i}$ is the country specific effects; $\lambda t$ is the time specific effects, and cit is the disturbance term that captures the effects of the omitted variables such as transaction cost, migration micro economic factors and the macro economic conditions in the host country of the migrants. With the application of the baseline model, the author compared estimates from Fixed Effects (FE) and Random Effects (RE) models. Empirical results of the study suggest the existence of a positive relationship between the level of financial development and inward remittances, which the author interpreted to mean that weaknesses in the formal financial infrastructure constrain the flow of remittances. Further evidence from OLS and GMM-IV estimate revealed that migrants remit more during economic adversity of their home country. In addition to the above, the study also revealed that the impact of the size of a country's monetary system on remittances is directly and indirectly linked to the level of macroeconomic stability in the country.

Adenutsi (2014) analyzed the implications of financial liberalization programme for international inflows with regard to the macroeconomic determinants and also the implications of remittances for economic growth and development in Sub-Saharan Africa (SSA) between 1980 and 2009. In that study the author initially addressed definitional and measurement issues relating to international remittances and financial liberalization, and thereafter provided an overview of the macroeconomic policy environment in postindependent SSA. The hypothesis, which the study sought to test is whether financial liberalization causes higher inflows of international migrant remittances through official channels to augment the scarce domestic financial resources, and to stimulate economic growth for sustainable development in capital starved SSA economies. To achieve this objective, System General Method of Moment, and Granger non-causality estimation procedures were undertaken. Empirical evidence from the study revealed the following: (i) that the macroeconomic factors that influence remittance inflows in SSA have varying characteristics rather than static impact in response to changing macroeconomic policy environment; (ii) macro economic factors have different influences on attracting remittances from abroad in relation to migrant duration status; (iii) international migrant remittances spur higher economic growth in SSA, with greater impact on SSA countries with relatively higher growth rates;(vi) migrant remittances exert significant positive developmental impact without evidence of moral hazard effects; (v) inward remittances contributed to reducing poverty and unemployment; and (vi) higher remittances inflows promote human welfare.

Mbutor (2010) introduced monetary policy dimension to remittances-economic growth nexus in Africa with special focus on Nigeria. The author noted that remittance inflows are linked to monetary policy through interest rate structure, exchange rate management, financial stability, 
efficiency of payment system, general economic stability as measured by inflation. He further argued that remittances inflow could rise when recipient economy grows faster than the host country under stable exchange rates. On the other hand, domestic currency depreciation will attract greater inflow of remittances for investment in real assets. In order to effectively capture the complex inter linkages amongst remittance and monetary policy variables, Vector Autoregressive (VAR) method was employed since it is dynamic and also allows simultaneity of activities among variables. In view of the complex interactions among the variables the authors adopted two stages. First stage isolates the strength of the channels of transmission of monetary actions due to the intervening variables; second stage traces the effects of policy actions through each of the intervening variables to flow of remittances.

Results from the net calculated effects indicate that if monetary policy action appreciates the naira by $1.4 \%$, remittances to Nigeria will increase by $0.03 \%$ in the year following the period. In the third period when monetary policy induce a depreciation of $5.9 \%$, the flow of remittances will contract by $0.09 \%$.

Oke, et al., (2011) examined the nexus between remittances and financial development in Nigeria from 1977 to 2009. The authors employed both OLS and GMM estimation techniques. Empirical evidence from the study suggested that remittances positively and significantly influence financial development in Nigeria, except credit to private sector that produced insignificant effect in the GMM estimation.

Olubiyi (2013) argued that while Nigeria has been experiencing continuous inflows of workers' remittances over time, the level of investment is still low. The evidence showed that there is a direct and positive relationship between financial development and investment on the one hand and governance institution and investment on the other hand. He further stated that all things being equal, sound and functioning financial institution should reduce credit constraints and provide access to credit for the existing and potential investors, thereby raising investment level of the country. On the contrary, in a country where financial development is shallow, access to credit will be difficult and such credit constraints could hamper investment.

In an attempt to obtain a clearer picture of the importance of remittance on investment climate in Nigeria, Olubiyi (2000) specified an investment function thus:

$$
\mathrm{INV}_{\mathrm{t}}=\left(\mathrm{rem}_{\mathrm{t}}, \text { inst }_{\mathrm{t}}, \mathrm{mp}_{\mathrm{t}}, \mathrm{rem}_{\mathrm{t}} \mathrm{inst}_{\mathrm{t}}, \mathrm{X}\right)
$$

Where, INV is private investment, rem represents workers remittances, inst is a measure of institutional quality, $\mathrm{mp}$ is monetary policy instrument and $\mathrm{x}$ represents other control variables that could affect investment.

Upon the estimation of the investment model using GMM-IV estimator it was found that remittances will only affect investment positively if governance institutions are right.

\section{ANALYTICAL FRAMEWORK}

The Generalized Method of Moment (GMM) proposed by Hansen (1982) is adopted for this study. The GMM estimator is more robust and dynamic, as it allows the regressor variables to depend on its past values. The attractiveness of GMM over other estimators like Ordinary Least Squares (OLS) and two stage Least Squares (2TSLS) is the possibility of obtaining consistent point estimates in the presence of heteroscedasticity, serial correlation and non linearity (White, 1984; Newey \& West, 1987). The 2TSLS uses a weighting matrix constructed under homoscedasticity while GMM estimator allows for the parameters to be over- identified (Craig, 
1983).

Following this a general linear regression model is specified as:

$$
\mathrm{Yi}=\mathrm{X}^{1}{ }_{\mathrm{t}} \beta+\mu \mathrm{t}
$$

The OLS estimator $\beta=\sum \mathrm{X}^{2} \mathrm{t}$ is consistent

For $\beta$ given $\mathrm{E}(\mathrm{ut} / \mathrm{x})=0$

A regression model with the first lagged dependent variable as a regressor can be specified from equation (7) as:

$$
\mathrm{Yi}=\mathrm{y}^{1} \mathrm{t}-1 \beta_{1}+\mathrm{X}^{1} \beta_{2}+\mu \mathrm{t}
$$

The model in equation (8) is a dynamic model chosen for parsimony and one lagged value of $\mathrm{y}_{\mathrm{t}}$ 1 provides the current information about $y_{\mathrm{t}}$. The regression errors $\mu$ i though uncorrelated with $\mathrm{xt}$ are correlated with $\mathrm{y}_{\mathrm{t}-1}$, the past value of $\mathrm{y}_{\mathrm{t}}$. The correlation leads to OLS estimator being inconsistent for $\beta$. The GMM estimator as proposed by (Hansen, 1982) therefore becomes consistent for $\beta$.

An instrument variable $\mathrm{Z}$ that is correlated with $\mathrm{y}_{\mathrm{t}-1}$ and uncorrelated with yt gives consistent estimation. This implies that $\mathrm{E}(\mathrm{ut} / \mathrm{Z})=0$, which gives the moment condition or population zero - correlation is expressed as:

$$
\mathrm{E}\left[\mathrm{Z}^{1} \mathrm{i}(\mathrm{yi}-\mathrm{xi} \beta]=0\right.
$$

Given equation (9) the models used for this study are specified as:

$$
D P_{t}=\alpha+\beta 1 D P_{t-1}+\beta 2 I_{t}+\beta 3 Z_{t}+\mu t
$$

Where DP is the dependent variable at time $\mathrm{t}, \alpha$ is the constant term , $\mathrm{DP}_{\mathrm{t}-1}$ one past value of the dependent variable, ID is independent variable, $Z$ is the vector of control variables, $\beta$ are parameters to be estimated and $\mu$ is the error term. The inclusion of the lagged dependent variable renders the OLS estimator biased and inconsistent as earlier mentioned which necessitates the use of GMM. Anderson and Hsiao (1981) in the context of GMM, proposed a strategy for handling this problem. They suggested taking the first difference (FD) transformation which eliminates the correlation between the lagged dependent variable and the error term. In difference notation the models become:

$$
\Delta \mathrm{DP}_{\mathrm{t}}=\alpha+\beta 1 \Delta \mathrm{DP}_{\mathrm{t}-1}+\beta 2 \Delta \mathrm{Z}_{\mathrm{t}}+\Delta \mu_{\mathrm{t} .}
$$

By first differencing the model, $\Delta \mu_{\mathrm{t}}$ becomes uncorrelated with $\Delta \mathrm{DP}_{\mathrm{t}-\mathrm{k}}$ for $\mathrm{k} \geq 2$ (Anderson \& Hsiao,1982). Where, $\mathrm{k}$ is the number of lags.

\section{MODEL SPECIFICATION}

\section{Impact of household inward remittances on banking Sector development in Nigeria}

This model is formulated to examine whether household inward remittances contribute to the development of the financial sector by increasing the aggregate amount of credit extended by the local banking sector to the private sector. 


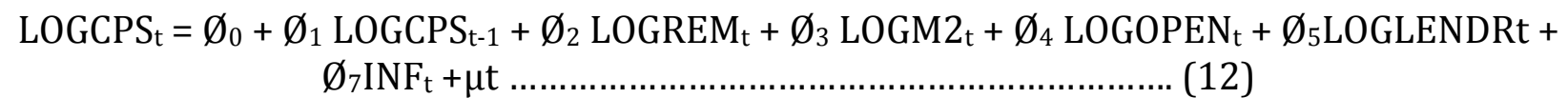

Where

- LOGCPS is the natural logarithm of credit to private sector; LOGCPS $\mathrm{L}_{\mathrm{t}-1}$ is one period lagged value of credit to private sector INF is inflation rate; LOGREM is the natural logarithm of household inward remittances; LOGPEN is the natural logarithm of trade openness; LOGM2 is natural logarithm of money supply and LOGLENDR is natural logarithm of lending rate $\emptyset_{0}$ is the intercept; $\emptyset_{1} \ldots . . . \emptyset_{7}$ are parameters to be estimated $\mu \mathrm{t}_{1}$ is the error term

\section{a priori expectation}

$\emptyset_{1}>0, \emptyset_{2}>0, \emptyset_{3}>0, \emptyset_{4}>0, \emptyset_{5}<>0, \emptyset_{6}>0$

\section{Trend of Remittance Inflows and Banking Sector Development in Nigeria}

There has been massive inflow of inward remittances over the years into the Nigerian economy through the formal financial system and there are reports that much more may have been remitted through informal financial system due probably to high transaction cost charged by banks.

In order to direct inward remittances to productive investment, the Central Bank of Nigeria has carried out several reforms aimed at deepening the Nigerian banking system.

Thirty seven years (1977- 2014) of Nigerian banking industry can be divided into five phases, namely: Indigenization Period (1977 - 1985); Market Deregulation Period (1986 - 1993); Guided Deregulation Period (1994 - 1998); Universal Banking Period (1999 - 2003); Consolidation Period (2004 - 2008); Restructuring Period (2009 - 2014)

\section{Indigenization Period (1977-1985)}

During indigenization period, inward remittances was not prominent in the Nigerian economy and this is understandable because of oil boom. Nigerians were not migrating because of relative strength of the Naira vis-à-vis other major currencies of the world.

Available data from the World Bank and Central Bank of Nigeria (CBN) showed that inward remittances as a share of GDP averaged $\$ 0.32 \mathrm{bn}$, while broad money supply and credit to private sector as a share of GDP was $\$ 28.13 \mathrm{bn}$ and $\$ 17.07$ respectively during the period. Despite these GDP declined by -0.96, Figure 1 below displays the trend of remittance inflows and banking sector development during the period 1977 to 1985 (World Bank, 2015).

\section{Market Deregulation Period (1986 - 1993)}

Between 1986and 1993, inward remittances increased marginally by $1.13 \%$ up from the average of $\$ 0.32 \mathrm{bn}$ recorded in the indigenization era to $\$ 0.68 \mathrm{bn}$ recorded in the market regulation era. (CBN 2013) However, the reverse was the case in the banking sector development in which both broad money supply (M2) and credit to private sector declined sharply. The broad money supply declined by $27.25 \%$ down from $\$ 28.13 \mathrm{bn}$ recorded in the indigenization era to 24.71 in the market regulation era. Similarly, credit to private sector contracted by $26.59 \%$ from $\$ 17.07 \mathrm{bn}$ recorded in the indigenization period to $\$ 12.5 \mathrm{bn}$ in the market regulation era (World Bank, 2015).

\section{Guided Deregulation Period (1994-1998)}

Similar to the market regulation era, this period also witnessed mixed performance with an 
impressive growth of inward remittances and GDP but with further decline in the banking sector development. For example, inward remittance made an impressive growth of $450 \%$ from the average $\$ 0.69 \mathrm{bn}$ received in the market regulation era to $\$ 3.74 \mathrm{bn}$ in the guided deregulation era. This is superlative growth in remittance inflows was driven by an increase in demand for Nigerian workers in the European region which accompanied the increase in oil prices. The increase in remittance flows, was followed by GDP growth by $2.2 \%$.However, the story is not the same with banking sector development. Broad money supply declined further by $26.54 \%$ from $\$ 24.75 \mathrm{bn}$ recorded in the proceeding era to $\$ 18.15 \mathrm{bn}$ in the guided deregulation era. Credit to private sector also recorded downward movement by $7.9 \%$ from $\$ 12.53 \mathrm{bn}$ in the market regulation era to $\$ 11.54 \mathrm{bn}$ in the guided deregulation era (World Bank, 2015).

\section{Universal Banking Period (1999-2003)}

In 1999, remittance inflows reached over \$13bn and amounted to $3.62 \%$ of Nigerian GDP, Universal Banking era also produced mixed performance with GDP, broad money supply and credit to private sector moving upward, but inward remittance headed downward. Available data showed that inward remittance declined by $31.2 \%$ down from $\$ 3.74 \mathrm{~b}$ recorded in Guided deregulation to $\$ 2.57 \mathrm{bn}$ in the Universal Banking era. However, GDP grew by $4.88 \%$, despite decline in inward remittance. Broad money improved by $23.14 \%$ up from $\$ 18.15 \mathrm{bn}$ recorded in the guided deregulation era to $\$ 22.3 \mathrm{bn}$ in the Universal Banking era similarly, credit to private grew by $20.10 \%$ up from $\$ 11.54$ recorded in the proceeding era to $\$ 13.86 \mathrm{bn}$ (World Bank, 2015).

\section{Consolidation Period (2004-2008)}

This is the period where all indicators, such as inward remittance as a share of GDP, broad money supply as a share of GDP, credit to private sector as a share of GDP and GDP growth all moved in the upward direction specifically, inward remittance increased substantially to $268 \%$ up from $\$ 2.57 \mathrm{bn}$ recorded in the Universal Banking era to all time high and peaked at $\$ 9.46 \mathrm{bn}$. Broad money supply also moved in similar direction at a percentage growth rate of $6.84 \%$ from $\$ 22.35 \mathrm{bn}$ in the Universal Banking era to $\$ 23.88 \mathrm{bn}$ in the consolidation era. In a similar vein credit to private sector reached on all time high at $42 \%$ from $\$ 13.86 \mathrm{bn}$ recorded in the proceeding period to $\$ 19.7 \mathrm{~b}$ recorded in the consolidation era (World Bank, 2015).

\section{Restructuring Period (2009 - 2014)}

Unlike the consolidation era that produced all-round improvement in all indicators. This period produced mixed result with a downward movement recorded in remittance inflows, credit to private sector and GDP declined with the exception of broad money supply that showed a marginal improvement. In specified terms remittance declined by $40.9 \%$ down from $\$ 9.46 \mathrm{bn}$ recorded in the consolidation era to $\$ 5.59 \mathrm{bn}$ in the restructuring era. In a similar vein, credit to private sector declined to all time low at $11 \%$ from $\$ 19.7 \mathrm{bn}$ recorded in the previous era to $\$ 17.53 \mathrm{bn}$ in the present era (World Bank, 2015). 


\section{TREND OF INWARD REMITTANCES AND BANKING SECTOR DEVELOPMENT}

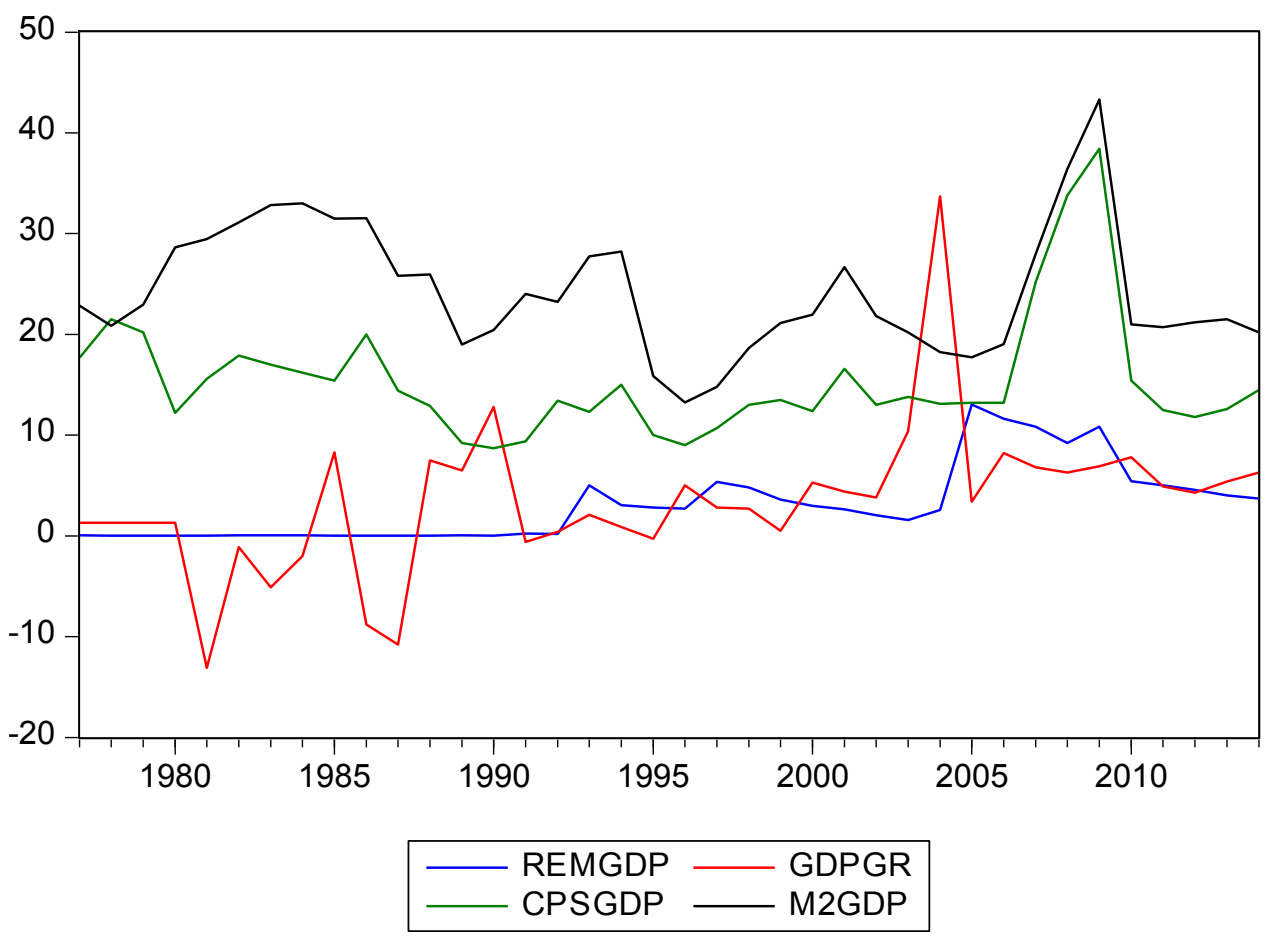

TIME SERIES PROPERTIES OF THE DATA

Table 2: Unit Root Test

\begin{tabular}{|c|c|c|c|c|c|}
\hline \multirow[t]{2}{*}{ Variable } & \multicolumn{3}{|l|}{ ADF(ILAG) } & \multicolumn{2}{|l|}{ PP*(3Lags) } \\
\hline & $\begin{array}{c}\text { With } \\
\text { constant (No } \\
\text { trend) }\end{array}$ & $\begin{array}{c}\text { With } \\
\text { constant \& } \\
\text { Trend }\end{array}$ & $\begin{array}{c}\text { With } \\
\text { constant (No } \\
\text { trend) }\end{array}$ & $\begin{array}{c}\text { With } \\
\text { constant } \& \\
\text { trend }\end{array}$ & $\mathrm{d}^{*}$ \\
\hline LREM & $-1.2978^{\prime}-$ & -1.4751 & -1.9022 & -2.7758 & $1(1)$ \\
\hline$\triangle$ LREM & 9.8686 & -9.7885 & -9.8686 & -9.7985 & \\
\hline $\begin{array}{l}\text { LCPS } \\
\Delta \text { LCPS }\end{array}$ & $\begin{array}{c}-3.7677 \\
-\end{array}$ & $\begin{array}{c}-3.7557 \\
-\end{array}$ & $\begin{array}{c}-3.6187 \\
-\end{array}$ & $\begin{array}{c}-3.5387 \\
-\end{array}$ & $1(0)$ \\
\hline $\begin{array}{l}\mathrm{INF} \\
\Delta \mathrm{INF}\end{array}$ & -6.0100 & -5.9546 & -10.7271 & -11.1529 & $1(0)$ \\
\hline $\begin{array}{l}\text { LLENDR } \\
\Delta \text { LLENDR }\end{array}$ & $\begin{array}{l}-2.3381 \\
-7.3933 \\
\end{array}$ & $\begin{array}{l}-2.1887 \\
-6.4429 \\
\end{array}$ & $\begin{array}{l}-2.2319 \\
-7.5709 \\
\end{array}$ & $\begin{array}{l}-2 / 0617 \\
-7.8481 \\
\end{array}$ & $1(1)$ \\
\hline $\begin{array}{l}\text { LOPEN } \\
\Delta \text { LOPEN }\end{array}$ & $\begin{array}{l}-2.1373 \\
-5.5033 \\
\end{array}$ & $\begin{array}{l}-2.1967 \\
-5.4594 \\
\end{array}$ & $\begin{array}{l}-2.2125 \\
-5.4975 \\
\end{array}$ & $\begin{array}{l}-2.3263 \\
-5.4864 \\
\end{array}$ & $1(1)$ \\
\hline $\begin{array}{l}\mathrm{LM} 2 \\
\Delta \mathrm{LM} 2\end{array}$ & $\begin{array}{l}-3.4192 \\
-6.5138 \\
\end{array}$ & $\begin{array}{l}-3.5392 \\
-6.4107 \\
\end{array}$ & $\begin{array}{c}-2.4413 \\
-12.4377 \\
\end{array}$ & $\begin{array}{c}-3.4475 \\
-11.7065 \\
\end{array}$ & $1(1)$ \\
\hline $\begin{array}{l}\text { MCKINNON } \\
\text { CRITICAL } \\
\text { VALUES: } \\
\text { LEVEL }\end{array}$ & & & & & \\
\hline $1 \%$ & $\begin{array}{l}-3.5253 \\
-2.9029 \\
\end{array}$ & $\begin{array}{l}-4.0928 \\
-3.4739 \\
\end{array}$ & $\begin{array}{l}-3.5239 \\
-2.9023 \\
\end{array}$ & $\begin{array}{l}-4.0909 \\
-3.4730 \\
\end{array}$ & \\
\hline $5 \%$ & $\begin{array}{l}-3.5267 \\
-2.9035 \\
\end{array}$ & $\begin{array}{l}-4.0948 \\
-3.4749 \\
\end{array}$ & $\begin{array}{l}-3.5233 \\
-2.9029 \\
\end{array}$ & $\begin{array}{l}-4.0928 \\
-3.4739 \\
\end{array}$ & \\
\hline
\end{tabular}

Source: Authors Computation from E-views7, 2017.

NOTES: ADF, PP, $d^{*}$ denotes Augmented Dickey Fuller, Phillips-Perron test and decision about the order of integration, respectively. 


\section{Cointegration Test}

The unit root results which indicate the order of integration of the variables is presented in table 2. The test show that the variables: CPS and INF are stationary at level I(0), while REM, LENDR, M2 and OPEN are stationary at first difference I(1). This implies that the null hypothesis of non stationary for all the variables is rejected. Given the unit -root properties of the variables, we proceed to establish whether or not a long -run relationship exist among the variables.

The Johansen cointegration tests revealed that the trace statistics show the existence of five cointegrating relationship and maximal eigenvalue statistics show the existence of one cointegrating relationship among the variables at the 5 percent level of significance (table 3 ). The conclusion drawn from this result is that there exist a long run relationship between REM, CPS, INF, LENDR, M2 and OPEN.

Table 3: Co integration Rank Test

VARIABLES: LCPS, LREM, LM22, INF, LOPEN, LENDR

\begin{tabular}{|c|c|c|c|c|c|}
\hline $\begin{array}{c}\text { Null } \\
\text { Hypothesis }\end{array}$ & $\begin{array}{c}\text { Trace } \\
\text { Statistics }\end{array}$ & $\begin{array}{c}\text { Critical } \\
\text { value @5\% }\end{array}$ & $\begin{array}{c}\text { Null } \\
\text { hypothesis }\end{array}$ & $\begin{array}{c}\text { Max Eigen } \\
\text { statistic }\end{array}$ & $\begin{array}{c}\text { Critical } \\
\text { value @ 5\% }\end{array}$ \\
\hline None* $^{*}$ & 119.3028 & 95.7536 & None & 34.1348 & 40.0775 \\
\hline At most 1* & 85.1678 & 69.8188 & At most 1 & 30.3665 & 33.8768 \\
\hline At most 2* & 54.8013 & 47.8561 & At most 2 & 23.3149 & 27.5843 \\
\hline At most 3* & 31.4863 & 39.7970 & At most 3 & 13.7155 & 21.1316 \\
\hline At most 4* & 17.7708 & 15.4947 & At most 4 & 11.9751 & 14.2646 \\
\hline At most 5* & 5.7957 & 3.8414 & At most 5* & 5.7957 & 3.8414 \\
\hline
\end{tabular}

Source: Authors computation from E-views 7, 2017

NOTE: $* * *)$ denotes rejection of the hypothesis at $5 \%(1 \%)$ significance 1

\section{RESULTS AND DISCUSSION}

Table 4 presents the GMM-IV estimate of banking sector development model. Proxied by credit to private sector (DLCPS). Here DLCPS is expressed as a function of a period lagged value of the dependent variable (DLCPS(-1)) natural logarithm of inward remittances as a ratio of GDP (DLREM), natural logarithm of broad money supply (DLM2), inflation rate (DINF) natural logarithm of trade openness measured as the ratio of the sum of import and export logarithm of lending rate (DLENDR). 
Table 4

Impact of household inward remittances on banking sector development

Instrument specifications: DLCPS(-3), DLCPS (-2) DLREM(-1), DLM2(-1), DINF(-1), DLOPEN(-1) DLLENDR(-1)

\begin{tabular}{|l|c|c|c|c|}
\hline $\begin{array}{c}\text { Explanatory } \\
\text { Variables }\end{array}$ & \multicolumn{5}{|c|}{ Dependent variable: DLCPS } \\
\hline & Coefficient & Std error & t-statistic & Prob. \\
\hline C & -1.8190 & 5.5626 & -0.3255 & 0.7475 \\
\hline DLCPS(-1) & 0.1336 & 0.7750 & 0.1724 & 0.8645 \\
\hline DLREM & 0.0727 & 0.1409 & 0.5165 & 0.6100 \\
\hline DLM2 & $1.5775^{* * *}$ & 0.5345 & 2.9509 & 0.0068 \\
\hline DINF & -0.0072 & 0.0218 & -0.3317 & 0.7428 \\
\hline DLOPEN & 0.2285 & 1.2552 & 0.1849 & 0.8547 \\
\hline DLLENDR & -0.1995 & 0.3292 & -0.6061 & 0.5499 \\
\hline Diagnostic statistics & & 0.47 & \\
\hline R-squared & & 0.22 & \\
\hline Adj. R-squared & & 0.00 & \\
\hline Durbin Watson Stat. & & & & \\
\hline J-statistic & & & & \\
\hline
\end{tabular}

Source: Authors computation from E-view 7, 2017

Note $^{* * *}, * *, *$ denotes significance at $1 \%, 5 \%$ and $10 \%$ respectively.

The coefficient of determination R-squared shows that $47.17 \%$ of the dependent variable can be explained by the explanatory variables. GMM estimate of equation (3.6) indicates that one year lagged value of private sector credit is positively related to current year credit to private sector but statistically insignificant. The coefficient of remittances is positively related to credit to credit to private sector but it is statistically insignificant. The coefficient of broad money supply (DLMS2) is positive and statistically significant at $1 \%$ level. Holding other variables constant a percentage change in broad money supply will culminate into $1.57 \%$ increase in credit to private sector. The coefficient of inflation and lending rate are negatively related to DLCPS but statistically insignificant. The coefficient of openness is positively related to DLCPS but statistically insignificant. These results are in conformity to our a priori expectation.

Result shows that inward remittances have positive but statistical insignificant impact on banking sector development proxied by credit to private sector as a share of GDP. There are 
several indicators of banking sector development such as; financial $\operatorname{dept(M2/GDP)~that~}$ measure the relative size of financial intermediaries as well as the degree of financial intermediation; total loan as a ratio of GDP(LOAN/GDP); and credit to private sector as a share of GDP(CPS/GDP). The later (CPS/GDP) is chosen in this study as a proxy for banking sector development because it is considered to be a better measure of banking sector development in literature because banking system that is capable of transmitting credit to private sector is considered more efficient than those banks that mobilize fund without creating value by way of loan or banks that channel loan to government. A positive relationship is observed between remittances and credit to private sector and is in conformity with our a priori expectation, in addition, the insignificant effect of remittances on credit to private sector is also consistent with the findings of Oke et al., (2011) who found positive but insignificant relationship between remittances and credit to private sector in Nigeria. The consistency of these results is reliable in view of the similarity of the methodology adopted in the two studies (GMM). Meanwhile, this result is not surprising to keen watchers in view of absolute lack of innovative remittance- linked products that will encourage remittance households and Diaspora Nigerians to save. Nigerian banks are yet to come to realization that remittance inflows is a veritable source of investment finance to capital starved Nigerian businesses. Nigerian banks merely serve as payment agents to money transfer operators such as Western Union and MoneyGram without value addition. Besides, there is this observed phenomenon where Nigerian banks prefer granting loans to public sector at the expense of private sector, probably due to moral hazard occasioned loan default by borrowers. It is possible that if the effect of remittance on total loan is examined the impact would be significant. This finding seems to lend credence to NELM Theory.

\section{CONCLUSION AND RECOMMENDATIONS}

This study examined the impact of household inward remittances on banking sector development and economic growth in Nigeria. The study also explored the channels through which inward remittances transmit to promote economic growth in Nigeria using Generalized Method of Moment (GMM) estimator proposed by Hansen(1982).

The study reveals that household inward remittances made positive impact on banking sector development in Nigeria, though the impact is negligible considering the huge amount of remittance inflows into the Nigerian economy. This finding is consistent with conclusion reached by earlier writers on this topic including Agu (2009), Guilaino and Ruiz-Arranz (2009), Ukeje and Obiechina (2013), Kanu and Ozurumba (2013) amongst others.

The current practice where few commercial banks merely serves as agents of global money operators (MTOs) such as Western Union and Moneygram further compound the limited impact of remittances inflows. This practice has put the billion dollar business into the hands of a few, creating an oligopolistic structure; with its attendant consequences of high cost that make informal channels attractive. It is therefore recommended that other development banks and non-banks financial institutions such as mega Microfinance banks and Bureau De Charge (BDC) operators be licensed to undertake remittances transaction business.

The situation in the Nigrian banking industry as regards remittances business is that banks merely serve as cash receipts centers for remittances without any value addition. It is recommended that Nigerian banks develop remittance-linked financial products for Nigerians in Diaspora and remittance recipient households instead of treating remittance receipts as a one off transaction without value addition. 


\section{References}

Abdih, Y., Chami, R. Dagher, J., \& Montiel, P. (2012). Remittnaces and institutions. Are remittances a curse? World Development, 40(4), 657-666.

Adams, R.H., \& Page, J. (2005). Do international migration and remittances reduce poverty in developing countries? World Development, 33(10), 1645-1669.

Adelman, I., \& Taylor, J.E. (1990). Is structural adjusment with a human face posisble? The case of Mexico. Journal of Development Studies, 26, 387-407.

Adenutsi D.E. (2011). Financial development, international migrant remittances and endogenous growth in Ghana. http://mpra.ub.unimuenchen.de/293301/

Aggarwal, R., Asli, D.K., Peria, M., \& Soledad, M. P. (2006). Do workers' remittnaces promote financial development? World Bank Policy Research Working Paper No. 3957. Washington DC: World Bank. Retreived from http://ssrn.com/absract $=923264$

Aggarwal, R., Asli, D.K., Peria, M., \& Soledad, M. P. (2006). Do workers' remittnaces promote financial development? World Bank Policy Research Working Paper No. 3957. Washington DC: World Bank. Retreived from http://ssrn.com/absract=923264

Aghion, P., \& Bolton, P. (1997). A theory of trickle -down growth and development. Review of Economic Studies, 64(2), 151-72.

Ajilore, T., \& Ikhide, S. (2012). A bound testing analysis of migrants remittances and financial development in selected sub-sahara African countries. The Review of Finance and Banking. 4(2), 79-96.

Akinpelu, Y.A., Ogunbi, O.J., Bada, O.T., \& Omojola, O.S.(2013). Effects of remittance inflows on economic growth of Nigeria. Developing Countries Studies 3(3),113-122.

Akkoyunlu, S. (2013). Remittances and financial development: Is there a direct link? Evidence from Turkish data. Barnerjee, A.V., \& Newman, A. (1993). Occupational choice and the process of development. Journal of Political Economy 101, 274-98.

Bettin, G., \& Zazzaro, A. (2012). Remittances and financial development: Subsitutes or complements in ecnomic growth?. Bulletin of Economic Research, 64(4), 509-536

Catteneo, C. (2008). International migration and poverty: A cross-country analysis. Available at:http://www.daglino.unimi.it/media/cataneo: Cristina.pdf

CBN, (2014). Annual reports and statement of acoounts. www.cbn.gov.ng

Chami, R. A., Barajas, T., Cosimano, C., Fullenkamp, C., Gapen, M., \& Montiel, P. (2008). Macroeconomic consequences of remittances. IMF Occasional Paper, No. 259.(Washington: International Monetary Fund)

Cooray, A. (2010). Migrant remittances, financial sector development and the government ownership of banks: Evidence from a group of non-OECD economies. Journal of International Financial Markets, Institutions and Money. 22(4), 936-987.

Craig, J.C. (1982). More efficient estimation in the presence of heteroscedasticity of unknown form. Econometrica, 51(3), 751-63.

Ezeoha A.E. (2013). Financial determinants of International Remittance flows to the sub-Saharan African Region. International Migration. Doi:10.1111/iniig.12061.

Galor, O., \& Zeira, J. (1993). Income distribution an macroeconomics. The Review of Economics Studies. 60(1), 3552.

Giuliano, P., \& Ruiz-Arranz, M. (2005). Remittances, financial development and growth. IMF Working Paper. No. $\mathrm{WP} / 05 / 234$.

Giuliano, P., \& Ruiz-Arranz, M., (2009). Remittances, financial development and growth. Journal of Development Economics, 90(1), 144-152.

Gupta, S., Pattillo., C., \& Wagh, S. (2009). Effect of remittances on poverty and financial development in SubSaharan Africa. World Development, 37(1), 104-115.

Hansen, L.P. (1982). Large sample properties of generalized method of moment estimators Econometrica, 50(4), 1029-1054.

Hatemi, J.A. (2008). Tests for co integration with two unknown regime shifts with an application to financial 
market integration. Empirical Economics. 35, 497-505.

Jongwanich, J. (2007). Workers' remittance economic growth and poverty in developing Asia and the Pacific countries. Unescap Working paper WP/07/01.

Kalim, R., \& Shahbaz, M. (2009). Remittances and poverty nexus: Evidence from Pakistan. International Research Journal of Financial Economics, 10(3), 46-59.

Kanu, S.I., \& Ozurumba, B.A. (2013). Migrant's remittances and economic growth in sub-Saharan Africa: Evidence from Nigeria, Ghana and South Africa. Interdisciplinary Journal of Contemporary Research in Business. 4(10), 537550.

King, R., \& Levine, R. (1993). Finance and growth: Schumpeter might be right. Quarterly Journal o Economics, 108, 717-737.

Mahedi, M. (2014). Workers' remittance inflow, financial development and economic growth: A Study on Bangladesh. International Journal of Economics and Finance. Doi:10.5539lijef.v6n8p247.

Mbutor, M.O. (2010). Can monetary policy enhance remittances for economic growth in Africa? The case of Nigeria. Journal of Economics and International Finance. 2(8), 156-163.

McKinnon, R.I. (1973). Money and capital in economic development. Washington D.C Brookling Institute.

Mundaca, G.B. (2005). Can remittances enhance economic growth? The role of financial market development. University of OSLO Mimeo

Newey, W.K., \& West, K.D. (1987). A simple positive semi-definie, heteroscedasticity and autocorrelation consistent covariance matrix. Econometrica, 55(3), 703-08.

Nyamongo, E.M., Misati, r.N., Kipyegon, L., \& Ndirangu, L. (2012). Remittances, financial development and economic growth in Africa. Journal of Economics and Business. 64, 240-260. DOI:10:1016/j.jeconbus.2012.01.001.

Oke, B.O., Uadiale, O.M., \& Okpala, O.P. (2011). Impact of workers' remittances on financial development in Nigeria .International Business Research, 4(4), 218-225.

Olubiyi, E.A. (2013). Workers' remittances, governance institution and private investment in Nigeria. The Review of Finance and Banking 6(1), 63-81.

Paulson, A., \& Towsend, R. (2000). Entrepreneurship and financial constraints in Thailand. Working Paper (Evanstron/Chicago, Illinois: Northwestern University.

Stark, O. (1991). The migration of labour. Cambridge. Cambridge University Press.

Stark, O., \& Bloom, D.E. (1985). The new economics of labour migration. American Economic Review, 75(2), 173178.

Taylor, J.E. (1999). The new economics of labour migration and the role of remittances in the migration process. International Migration, 37(1), 63-88.

White, H. (1984). Asymptotic theory for econometrics. Orlando Fla. Academic Press.

World Bank, (2012). World Development Indicators 2012. Washington, D.C. World Bank

World Bank, (2013). World Development Indicators (WDI): online Database, The World Bank, Washington, D.C. USA. 